\title{
Projection of Nursing Profession in Malaysia: Where We Are and What Need to be Improved?
}

\section{Sowtali SN*}

International Islamic University Malaysia, Malaysia

*Corresponding author: Siti Noorkhairina Sowtali, International Islamic University Malaysia, ext: 7319 H/P: 012-7264236, Tel: 09-5706000; Email: Opinion
Volume 3 Issue 1
Received Date: January 16, 2018
Published Date: February 04,2019
DOI: $10.23880 /$ nhij-16000174 sitinoorkhairina@iium.edu.my

\section{Abstract}

Nursing profession in Malaysia has gone through several paradigm shift since it began in early $19^{\text {th }}$ century. At that particular time, hands-on approach is the medium of educating the young nurses adopted by the British doctors and nurse supervisors. Later on, the academia world of Nursing profession had evolved into several stage of qualification offerings such as Diploma/Advance Diploma, Degree/Bachelor, Master and Doctor of Philosophy to fulfill the requirement stipulated by the Ministry of Health, Malaysia Qualification Assurance and Ministry of Higher Education. This is in line of becoming a developed nation whereby there is a need to produce more postgraduate holder and research study in critical area which includes Nursing. Therefore, nurses role are now expand not only limited to clinical setting but require various expertise in academic, research and top division management of the Nursing profession. Thus, there is a need to recruit more male nurses, creating a clinical nurse specialist post to avoid 'brain drain' of the geniuses and to reduce burnout issues among Malaysian nurses. More support and supervision from the universities or colleges' management is needed especially to motivate the nurses with Master and Doctor of Philosophy to get involve in research and publication since the acceptance is still at low or moderate level in certain institutions. Since nurses are the heart of the healthcare team with multitasking role, there is also a need to look upon their welfare by various responsible organizations in the future.

Keywords: Nursing; Clinical Nurse Specialist; Academic; Research; Management; Welfare

Abbreviations: WHO: World Health Organization; UNICEF: United Nations International Children's Emergency Fund; CNS: Clinical Nurse Specialist; MOH: Ministry of Health; KKM: Kementerian Kesihatan Malaysia; STPM: Sijil Tinggi Pelajaran Malaysia; MQA: Malaysia Qualifications Agency; MOHE: Ministry of Higher Education; NBM: Nursing Board Malaysia; LJM: Lembaga Jururawat Malaysia; JPA: Jabatan Perkhidmatan Awam; ICU: Intensive Care Unit; CCU:
Cardiac Care Unit; OT: Operation Theatre; MNU: Malaysia Nurse Union; MNA: Malaysia Nurse Association; CNS: Clinical Nurse Specialist.

\section{Historical Background of Nursing Profession in Malaysia}

Nursing profession had evolved from the Islamic history towards modern era for a better nursing care 


\section{Nursing \& Healthcare International Journal}

service to the community. In Malaysia, nursing profession had begun during the $19^{\text {th }}$ century era after World War II and Communist attack [1]. At that time Malaysia was known as Malaya. The initial nursing schools were started in Penang, Johor Bahru and Kuala Lumpur under the sponsorship of World Health Organization (WHO) and United Nations International Children's Emergency Fund (UNICEF) for staffing as well as facilities [2]. The staff nurses in $19^{\text {th }}$ century era mainly were trained by the British matrons, sisters and medical doctors with hands on approach during clinical training [3]. At that time, the nurses were only awarded with certificate level of qualification once the training is completed.

\section{Education and Training for Career Enhancement}

Now, in the $21^{\text {st }}$ century era, the certification level has been upgraded to a minimum diploma qualification with a minimum of three (3) years training. Besides that, clinical nurse specialist (CNS) training is also introduced to sharpen and developed a more specialized skills and knowledge via post-basic courses [4,5]. Several post-basic courses offer by Ministry of Health (MOH)/Kementerian Kesihatan Malaysia (KKM) and private clinical setting (as in-house training) between six (6) months to 18 months duration are Midwifery, Renal Nursing, Intensive Care Nursing, Diabetes Educator, Perioperative Nursing, Wound Nursing, Coronary Care Nursing, Respiratory/Cardiac Technician and Intensivist. Currently, certain institutions had recognized the post-basic training as an Advanced Diploma to value its specialization for professional certification. To date, there are almost 32,411 nurses in Malaysia having post-basic qualification based on the Nursing Division, MOH statistical databases Table 1.

\begin{tabular}{|c|c|c|}
\hline No. & State in Malaysia & Total \\
\hline 1 & Perlis & 490 \\
\hline 2 & Kedah & 2,715 \\
\hline 3 & Pulau Pinang & 1,562 \\
\hline 4 & Perak & 3,166 \\
\hline 5 & Selangor & 3,207 \\
\hline 6 & $\begin{array}{c}\text { State Health Division (Jabatan } \\
\text { Kesihatan Wilayah Persekutuan), } \\
\text { Kuala Lumpur }\end{array}$ & 844 \\
\hline 7 & Hospital Kuala Lumpur & 1,766 \\
\hline 8 & $\begin{array}{c}\text { Medical Respiratory Institution } \\
\text { (Institut Perubatan Respiratori) }\end{array}$ & 26 \\
\hline 9 & $\begin{array}{c}\text { National Blood Centre (Pusat Darah } \\
\text { Negara) }\end{array}$ & 19 \\
\hline 10 & National Cancer Institute (Institut & 66 \\
\hline
\end{tabular}

\begin{tabular}{|c|c|c|}
\hline & Kanser Negara) & \\
\hline 11 & $\begin{array}{c}\text { State Health Division (Jabatan } \\
\text { Kesihatan Wilayah Persekutuan), } \\
\text { Labuan }\end{array}$ & 145 \\
\hline 12 & Negeri Sembilan & 1,434 \\
\hline 13 & Melaka & 1,212 \\
\hline 14 & Johor & 3,121 \\
\hline 15 & Pahang & 2,020 \\
\hline 16 & Terengganu & 1,913 \\
\hline 17 & Kelantan & 2,476 \\
\hline 18 & Sarawak & 2,666 \\
\hline 19 & Sabah & 3,563 \\
\hline \multicolumn{2}{|c|}{ TOTAL } & $\mathbf{3 2 , 4 1 1}$ \\
\hline
\end{tabular}

Table 1: Number of nurses holding post-basis qualification based on state in Malaysia $(\mathrm{N}=32,411)$.

(Source: Nursing Division, Ministry of Health, Malaysia, 2018)

Furthermore, there is another pathway in nursing studies which offer a degree level certification for a student with a background of Diploma in Nursing, Matriculation and Sijil Tinggi Pelajaran Malaysia (STPM)/A Level. Later on, the graduated degree nursing students may have the chances to pursue nursing study at a higher level [6,7]. These include Master (Master in Nursing Education, Nursing Science, Biobehavioral Science, Health Sciences with specialization) and Doctor of Philosophy (Ph.D).

Higher level education and training are only offered at selected local and private universities under the approval and accreditation of Malaysia Qualifications Agency (MQA) along with Ministry of Higher Education (MOHE). Students in higher education institutions are trained by the nurses with a minimum qualification of Degree/Master/Ph.D either with a specialization or not. In Malaysia, the Nursing curriculum encourage the blended learning application strategy along collaborative learning by the multidisciplinary healthcare professional such as by Physician, Dietician, Physiotherapist / Occupational Therapist, Pharmacist and not least to mention by Welfare / Religious Officer. The rationale of this approach is to prepare the nursing students into a real work life setting once they are graduated which demand them to be multitasking and becoming a mediator with many experts.

However, to date the exact number of nurses holding the Degree, Master and Ph.D have not been finalized yet which is something need to be done collaboratively by the Malaysian Nursing Council of the Public Institutions of Higher Learning (Jemaah Kejururawatan IPTA), NBM along with the help from the MOHE. It is important to 


\section{Nursing \& Healthcare International Journal}

produce statistical database of nurses with degree qualification and above (Master/Ph.D) at practice, management, research and academic settings for quality management in service. Many research done previously has proven that having a nurse with degree or having specialization (e.g. post basic training or advance diploma qualification) able to reduce medication error, able to reduce mortality rate as much as $70 \%$ among patients undergone for surgery (due to a better leadership along having nurses with higher critical and creative skills to produce safe and quality nursing care (Johnson, 1998 and Good, 2001) as cited by Siti Noorkhairina S (2012) [7].

\section{Bridging the Gap between Academic and Clinical}

Although nurses in Malaysia has put their initiative to pursue higher level of training for professional development or personal interest, but the career pathway is still not clear to date. This issue is not new but need further attention of the top management in Nursing Division at the Ministry level. Serious efforts and collaborations between Nursing Board Malaysia (NBM)/Lembaga Jururawat Malaysia (LJM), MOH, Public Service Department/Jabatan Perkhidmatan Awam (JPA) and Malaysian Nursing Council of the Public Institutions of Higher Learning (Jemaah Kejururawatan IPTA) in producing appropriate proposal on relevant post for nursing profession development [8,9]. Or else, demotivation and burnout among Malaysian nurses will set in since the effort is not appropriately valued by the management of the healthcare system itself [10]. This will lead more nurses looking forward an opportunity working in abroad such as Europe, Saudi Arabia, Brunei and Singapore since the salary is lucrative and paid equally according to their qualification.

Therefore, more specialized post for nursing academic, management, research and clinical should be developed and proposed to relevant authority based on the academic qualification held by our Malaysian nurses. This is especially important for nurses who had their Degree/Bachelor, Master or Ph.D along with their Postbasic specialization/Advanced Diploma training in-hand. Nurses' intellectual development should not be taken for granted and measures shall be taken to nurture the profession. Development of proper pathway of professional and job position for nurses based on their qualification is vital to be at par with other healthcare professional such as medical doctor, pharmacy, dietician, dentist and etc. Nevertheless, the mental set of the nurses' itself must be changed to portray their confident and critical thinking when it comes to decision making of their patients or students. This is to ensure the qualification behold by them is worth to enable their post to be upgraded.

\section{Research Involvement}

There is also a need for more nurses to be involved in collaboration research especially between local university and the industry (clinical setting at government or private hospital, primary care centre, academic centre, school setting etc). This is a responsibility shall be shouldered by nurses with a degree qualification and higher under the supervision of a specialized research team. Passion should be developed among nurses in research to produce evidence-based outcome for nursing care improvement at various setting. Nurses with higher qualification such as Master/Ph.D should be supported and supervised by the management for an opportunity to hold research grant (e.g. in-house allocation, external-local or international collaborators) and publish their findings. This network must be established to ensure gaps between the academia world and clinical setting could be reduced and research are carry out appropriately to the need of the healthcare settings.

Furthermore, more nurses from nursing profession need to conduct a research which integrates the scientific element quantitatively in order to produce a result that can be generalized to the population of interest. This is important especially to fulfill the needs of evidence-based outcome with numerical output which commonly the interest of researchers, funders and collaborators. Nevertheless, other approaches in nursing research such as qualitative study or mixed method study should not be left out. Certain issues in regards to spiritual matter, perceptions, psychology, sociology or emotions can be best explored using qualitative research approach. Scientific issues should not be looked as a separate entity (quantitative or qualitative) since nurses are handling their patients care holistically between these entities. For example, in pain management, we need both measures the pain score (quantitative data) and explore the best remedies which may help to reduce pain (qualitative data).

Other than the issues above, there are another important aspect in research should be a focus. Culturally sensitive element shall be integrated in the research study whereby allowing the immigrants, foreigners or aborigines to become research participants must be considered. We commonly neglect or limit the participation of minorities in research due to certain 


\section{Nursing \& Healthcare International Journal}

policy or ethical issues. However, in becoming a developed nation in less than few years ahead, Malaysia shall open the chances to cater the needs of its citizen disregard whether they are holding a full citizenship, permanent resident or immigrant/social worker. These research efforts may invite funders or collaborators from our neighbourhood countries. At the same time, we may obtain some findings from the minorities' perspective throughout their stay in Malaysia.

\section{Male Nurse Demand}

Currently, there is still lack of male figure entering the nursing program be it at Diploma or Degree/Bachelor level [3]. Table 2 highlights vast gap between the number of female nurses towards the male nurses with ratio of
36:1 working with $\mathrm{MOH}$ (not include private and university hospitals) in Malaysia. Yet, the number of male nurses are in demand especially for critical care area such as in Trauma Department (ANE), Intensive Care Unit (ICU), Orthopaedics and Rehabilitation, Cardiac Care Unit (CCU) as well as Operation Theatre (OT). There is a need to highlight this matter since we need the 'brain', energy, leadership and fast decision making by male nurses in nursing care either at the clinical site, during curriculum development in academia, policy setter in nursing management and experts' opinion for research area. Sooner or later, the male nurse will hold a post in such area to improve the Malaysia healthcare system as what being practiced in Canada, America, Australia and United Kingdom.

\begin{tabular}{|c|c|c|c|c|}
\hline No. & State in Malaysia & Female Nurse & Male Nurse & Total \\
\hline 1 & Perlis & 1,195 & 29 & 1,224 \\
\hline 2 & Kedah & 6,183 & 117 & 6,300 \\
\hline 3 & Pulau Pinang & 4,389 & 123 & 4,512 \\
\hline 4 & Perak & 7,710 & 200 & 7,910 \\
\hline 5 & Selangor & 10,835 & 406 & 11,241 \\
\hline \multirow{2}{*}{6} & $\begin{array}{c}\text { State Health Division (Jabatan Kesihatan } \\
\text { Wilayah Persekutuan), Kuala Lumpur }\end{array}$ & 2,222 & 56 & 2,278 \\
\hline 7 & Hospital Kuala Lumpur & 3,645 & 287 & 3,932 \\
\hline 8 & Medical Respiratory Institution (Institut & 4 & 98 \\
\hline 9 & Nerubatan Respiratori) & 94 & 18 & 131 \\
\hline 10 & National Blood Centre (Pusat Darah Negara) & 113 & 28 & 506 \\
\hline 11 & Sancer Institute (Institut Kanser & 478 & 1 & 339 \\
\hline 12 & Negara) & 338 & 99 & 3,526 \\
\hline 13 & Wilayah Persekutuan), Labuan & 3,427 & 76 & 2,809 \\
\hline 14 & Negeri Sembilan & 2,733 & 329 & 8,662 \\
\hline 15 & Melaka & 8,333 & 61 & 5,723 \\
\hline 16 & Johor & 5,662 & 26 & 4,274 \\
\hline 17 & Pahang & 4,248 & 41 & 5,144 \\
\hline 18 & Terengganu & 5,103 & 169 & 8,492 \\
\hline 19 & Kelantan & 8,323 & 2,96 & 10,777 \\
\hline & Sarawak & 10,481 & $\mathbf{2 , 3 6 6}$ & $\mathbf{8 7 , 8 7 8}$ \\
\hline
\end{tabular}

Table 2: Number of nurses working with Ministry of Health Malaysia according to state and gender $(\mathrm{N}=87,878)$.

(Source: Nursing Division, Ministry of Health, Malaysia, 2018).

\section{Nurses Role in Policy Making}

In Malaysia, rarely nurses are invited by the $\mathrm{MOH}$ or NBM authority to involve in a serious coffee table talk to improve the profession development in the healthcare system. Only certain nurses are commonly selected for such opportunity especially those from management background. Recruiting the younger generation to be in the pipeline of national leadership and policy setting is important to avoid 'brain drain' of the genius nurses. Nevertheless, the veteran and senior management should be more open-minded and work synergistically with the 


\section{Nursing \& Healthcare International Journal}

younger generation to ensure sustainability of the profession as time goes on. Meanwhile, the younger generation should have more respect towards the veteran and senior management but feel free to bring new ideas for open discussion. Merging both generations' ideas and opinions should be an ultimate aim when developing a policy or guideline for the betterment of healthcare system particularly for nursing profession.

\section{Welfare of Nurses}

In Malaysia, we have Malaysia Nurse Union (MNU) looking after the nurses' welfare for example to fight for their rights of not being harass in the working environment, social community or spouse. Most of healthcare and education industry related to Nursing profession had established linkages with Social Security Organization (SOCSO)/Pertubuhan Keselamatan Social (PERKESO) to cover for any disability development during working hour due to injury/accident for both the nurse and their dependent [11]. Meanwhile, Malaysia Nurse Association (MNA) did provide continuous platform for personal, professional and learning development for its member such as organizing seminars and conferences $[12,13]$.

In the future, MNA should lobby with MOH, JPA and NBM to give certain authority for nurses' management in the hospitals or academic to stand alone in its leadership and administrative task without any interference by the medical doctor or other healthcare professionals managerial. For example, we need the position for clinical nurse specialist (CNS) who can decide independently for nursing care and giving relevant consultation for their patients. Nevertheless, the CNS still working collaboratively with other healthcare multidisciplinary team for holistic care management for that particular patient [4]. This is proven by the quality of nursing care service delivered by our neighbourhood nurses such as Singapore, Thailand and Indonesia via their CNS as cited by Siti Noorkhairina S (2012) [7].

They had started developed such specialization in fact from their Degree/Bachelor program. Therefore, development for such position is vital especially for our nurses who held specialization training along their Master or Ph.D qualification. Rigidity should be reduced in allowing such changes in developing the profession to fulfil the vision of 2020 for Malaysia to become a developed nation. Prior to such changes, nurses and the management team shall look at where we are in the past, present and something need to be done for the future. Though, the hard work will not be received at our generation but the platform is nurture for the next generation of 'newbies'.

\section{Conclusion}

Nurses is the heart of the healthcare system thus providing offers in pursuing academic or training alone to improve nursing care is vital. However, it is not adequate if relevant post is not able to cater the number of nurses with a Degree / Master / Ph.D qualification especially if they are in the clinical setting. Nurses care the community from 'womb' to 'tomb' and they deserve to be valued and appreciated by ensuring a proper career pathway enhancement, allowing them to be the talk-person in policy making and ensuring their safety while working. Something to be improved in the future!

\section{References}

1. Siti Roshadai, MA (2016) History of Nursing. Kulliyyah of Nursing, International Islamic University Malaysia, Kuantan Campus, Malaysia.

2. Meriati M (2016) Nursing Development in Malaysia and International. Kulliyyah of Nursing, International Islamic University Malaysia, Kuantan Campus, Malaysia.

3. Siti Noorkhairina S (2017) Keperluan Jururawat Lelaki. Dewan Masyarakat 4: 20-24.

4. National Association of Clinical Nurse Specialists of United State of America (2017) What is a Clinical Nurse Specialist?

5. Burton C, Gibbon B (2005) Expanding the Role of the Stroke Nurse: A Pragmatic Clinical Trial. J Adv Nurs 56(2): 640-650.

6. (2018) Official Portal of Public Service Department.

7. Siti Noorkhairina S (2012) Evolution of Nursing Profession in Malaysia. Dewan Masyarakat 50(9): 2324.

8. (2016) The Official Portal of Malaysia Qualifications Agency (MQA), Ministry of Higher Education.

9. (2015) Official Portal of Nursing Division, Ministry of Health $(\mathrm{MOH})$.

10. Fatimah S, Siti Munirah AW, Nur Adilah O, Eazalela AR, Nur Aimi KA (2017) Burnout among Nurses in 


\section{Nursing \& Healthcare International Journal}

Clinical Training Centre, Selangor. The Malaysian Journal of Nursing 9(2): 71-77.

11. Official Website Social Security Organization (SOCSO) (2017) PERKESO Prihatin.

12. (2017) Malaysian Nurses Association, Professional Nurses Association for Malaysian Nurses.
13. Ramlah M (2017) Experts' Opinion on Malaysia Nurse Union and Malaysia Nurse Association Seminar Presentation. Kulliyyah of Nursing, International Islamic University Malaysia, Kuantan Campus, Malaysia. 